\title{
PENGEMBANGAN PRODUK KERUPUK IKAN BANDENG DI KABUPATEN GRESIK DENGAN MENGGUNAKAN METODE QUALITY FUNCTION DEPLOYMENT (QFD)
}

\author{
Narto \\ Program Studi Teknik Industri, Universitas Qomaruddin \\ Email: nartonazriel@gmail.com
}

\begin{abstract}
ABSTRAK
Kerupuk ikan bandeng merupakan hasil UKM unggulan di Kabupaten Gresik. Dengan kondisi geografis yang mempunyai pontensi tambak yang menghasilkan ikan bandeng. Banyaknya budidaya ikan bandeng yang dapat dihasilkan dari tambak yang berada di pesisir utara kabupaten Gresik memiliki nilai potensial tinggi untuk dimanfaatkan sebagai produk olahan ikan. Semakin hari semakin melimpah, tidak menutup kemungkinan jika suatu hari pasar mengalami kejenuhan akan kebutuhan ikan bandeng, karena masing-masing produk selalu memiliki siklus hidup produk. Untuk meningkatkan pemanfaatan bahan baku pembuatan kerupuk ikan bandeng di kabupaten Gresik maka perlu dilakukan strategi pengembangan produk melalui voice of customer dengan menggunakan metode Quality Function Deployment. Hasil penelitian diperoleh atribut - atribut yang dapat diprioritaskan pertama adalah perbaikan proses produksi dari mulai penggunaan bahan baku utama yaitu ikan bandeng dengan ukuran yang seragam. Pengolahan yang sesuai dengan standar keamanan untuk makanan. Penggunaan mesin giling yang higienis. Kebersihan dan sterilisasi ruang produksi. Proses penjemuran dengan menggunakan oven untuk menghasilkan kualitas kerupuk ikan yang mempunyai tingkat kekeringan merata. Pengembangan yang kedua yaitu memberikan pelayanan pelanggan melalui sistem terintegrasi dengan penggunaan teknologi informasi. Pengembangan yang ketiga yaitu pembuatan desain bentuk dan ukuran dengan motif sesuai dengan keinginan konsumen.
\end{abstract}

Kata kunci: $U K M, H o Q$, Technical matrix, $Q F D$

\section{Pendahuluan}

Kabupaten Gresik merupakan salah satu kabupaten yang berada di provinsi Jawa Timur dengan letak geografis yang berdekatan langsung dengan pesisir laut jawa. Banyaknya budidaya ikan bandeng yang dapat dihasilkan dari tambak yang berada di pesisir utara kabupaten Gresik memiliki nilai potensial tinggi untuk dimanfaatkan sebagai produk olahan ikan. Salah satu produk hasil olahan ikan yang banyak di produksi adalah kerupuk ikan bandeng. Ketersediaan bahan baku yang mudah diperoleh tidak menyulitkan dalam proses pengolahan kerupuk ikan bandeng. Produksi bandeng yang semakin hari semakin melimpah, tidak menutup kemungkinan jika suatu hari pasar mengalami kejenuhan akan kebutuhan ikan bandeng, karena masing-masing produk selalu memiliki siklus hidup produk [1]. Berdasarkan data Kementerian Kelautan dan Perikanan pada Tahun 2018 produksi perikanan nasional mencapai angka 6.242.846 ton [2].

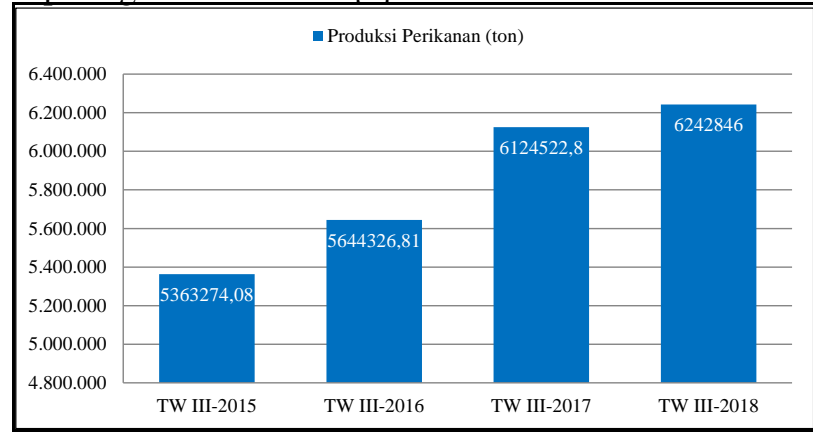

Gambar 1. Tingkat Produksi Perikanan Nasional Tahun 2018

Untuk meningkatkan pemanfaatan bahan baku pembuatan kerupuk ikan bandeng di kabupaten Gresik maka perlu dilakukan penelitian sehingga penggunaan bahan baku dapat diolah menjadi produk yang yang mempunyai nilai ekonomis tinggi. Setiap usaha perlu penerapan pengelolaan usaha dengan baik termasuk dalam pengelolaan produksi [3]. Ketersediaan bahan baku yang tinggi maka mempunyai potensi untuk mengembangkan produk kerupuk ikan bandeng di kabupaten Gresik. 


\section{KAIZEN : MANAGEMENT SYSTEMS \& INDUSTRIAL ENGINEERING JOURNAL VOL. 2 NO. 2 TEKNIK INDUSTRI UNIVERSITAS PGRI MADIUN}

Pengembangan produk sebaiknya menggunakan metode yang terstruktur [4]. Pengembangan produk diharapkan dapat memuaskan dan memenuhi kebutuhan manusia [5]. Pengembangan produk harus diawali dengan identifikasi kebutuhan konsumen bertujuan untuk mengetahui atribut-atribut yang penting dan berhubungan dengan kepuasan pelanggan sebagai dasar dalam langkah pengembangan produk selanjutnya [6]. Pengembangan ini dapat meningkatkan kualitas, produktivitas, serta mempermudah pekerjaan manusia dalam melakukan proses produksi [7].

QFD merupakan sebuah metode perencanaan dan pengembangan produk terstruktur yang memungkinkan team pengembangan untuk menentukan secara jelas kebutuhan dan keinginan konsumen dan kemudian mengevaluasi kapasitas setiap pengembangan produk dan jasa secara sistematis [8]. QFD merupakan pendekatan yang sistematik dalam menentukan apa yang diinginkan konsumen dan menerjemahkan keinginan tersebut secara akurat kedalam disain teknis, manufacturing dan perencanaan produksi yang tepat [9]. Pengembangan produk adalah semua proses yang berhubungan dengan keberadaan produk yang meliputi segala aktivitas mulai dari identifikasi keinginan konsumen sampai fabrikasi, penjualan dan pengiriman produk [10]. Secara singkatnya, QFD merupakan suatu perangkat manajemen dimana keinginan konsumen digunakan sebagai alat untuk pengembangan produk [11]. Dengan demikian pelaku usaha dapat meningkatkan pelayanan terhadap konsumen dengan melakukan penelitian untuk mengetahui Voice Of Customer sebagai dasar untuk perencanaan pengembangan produk yang lebih lanjut menggunakan metode Quality Function Deployment [12].

\section{Metode Penelitian}

Penelitian dilakukan pada UKM kerupuk Ikan Bandeng di Kabupaten Gresik, dengan pertimbangan bahwa di kabupaten Gresik banyak terdapat tambak yang membudidaya ikan bandeng sebagai bahan baku utama pembuatan kerupuk ikan bandeng. Data peleitian terdiri dari data primer dan sekunder. Data primer merupakan hasil pengamatan langsung dan melalui hasil penyebaran kuesioner dengan menggunakan skala likert, kuesioner dibagikan kepada konsumen kerupuk ikan bandeng di kabupaten Gresik dengan metode sample untuk mengetahui tingkat kepentingan dan persepsi pelanggan melalui penyusunan atribut kebutuhan konsumen (whats), sedangkan data sekunder diperoleh dari literatur. Setelah data kuesioner terkumpul dilakukan uji validitas dan reliabilitas. Tahap selanjutnya yaitu menyusun House of Quality (HoQ) yang terdiri dari voice of customer, matrik perencanaan, penentuan respon teknis, matrik hubungan dan prioritas, analisis hasil dan interpretasi.

\section{Hasil dan Pembahasan}

Hasil dari penelitian ini didasarkan oleh metode penelitian. Tahapan terhadap hasil dan pembahasan terhadap penelitian ini sebagai berikut

1. Penyusunan Atribut Kebutuhan konsumen

Penelitian dilakukan untuk menyusun strategi pengembangan produk kerupuk ikan bandeng yang sesuai dengan keinginan pelanggan. Penyebaran kuesioner dilakukan kepada 80 orang reseponden menggunakan Sampling dengan penilaian menggunakan skala likert. Kuesioner akan menghasilkan kepentingan dan persepsi pelanggan terhadap produk kerupuk ikan bandeng. Pengumpulan data atribut kebutuhan konsumen (whats) dikelompokan berdasarkan dimensi yang ditunjukan pada Tabel 1 dibawah ini.

Tabel 1. Dimensi dan Kebutuhan Konsumen (Whats)

\begin{tabular}{|c|c|c|}
\hline No. & Dimensi & Kebutuhan konsumen (Whats) \\
\hline \multirow[t]{2}{*}{1} & \multirow{2}{*}{ Performance \& Durability } & 1. Bahan baku berkualitas baik \\
\hline & & 2. bahan pendukung berkualitas baik \\
\hline \multirow[t]{2}{*}{2} & \multirow[t]{2}{*}{ Feature } & 3. Kerupuk ikan sebagai pelengkap makan \\
\hline & & 4. Sebagai makanan camilan ringan \\
\hline \multirow[t]{2}{*}{3} & \multirow[t]{2}{*}{ Reliability } & 5. Harga terjangkau \\
\hline & & 6. Harga sesuai kualitas atau manfaat \\
\hline \multirow[t]{2}{*}{4} & \multirow[t]{2}{*}{ Conformance } & 7. Ukuran dan ketebalan irisan bervariasi \\
\hline & & 8. Bentuk kerupuk ikan yang bervariasi \\
\hline \multirow[t]{2}{*}{5} & \multirow[t]{2}{*}{ Serviceability } & 9. Customer sevice untuk keluhan pelanggan \\
\hline & & 10. Jaminan dalam waktu tertentu \\
\hline \multirow[t]{2}{*}{6} & \multirow[t]{2}{*}{ Estetika } & 11. Kerupuk ikan bermotif menarik \\
\hline & & 12. Penggunaan packaging menarik \\
\hline \multirow[t]{2}{*}{7} & \multirow[t]{2}{*}{ Perceived Quality } & 13. Kemudahan memperoleh produk \\
\hline & & 14. Jaminan kesehatan saat konsumsi \\
\hline
\end{tabular}

Copyright (C) 2019, Kaizen : Management Systems \& Industrial Engineering Journal ISSN 15222-96806 (print), ISSN $155222-95973$ (online) 


\section{KAIZEN : MANAGEMENT SYSTEMS \& INDUSTRIAL ENGINEERING JOURNAL VOL. 2 NO. 2 TEKNIK INDUSTRI UNIVERSITAS PGRI MADIUN}

Terdapat 7 dimensi seperti pada Tabel 2 dan 14 atribut kebutuhan konsumen (whats) seperti pada Tabel 3 yang diperoleh dari hasil pengumpulan data menggunakan kuesioner. Selanjutnya yaitu menentukan respon teknis (hows) sebagai tanggapan perusahaan dan gagasan yang akan digunanakan dalam pengembangan produksi produk kerupuk ikan bandeng.

Tabel 2. Respon Teknis Produk Kerupuk Ikan Bandeng Gresik

\begin{tabular}{|c|l|}
\hline No. & Respon Teknis (hows) \\
\hline 1 & Jenis bahan baku \\
\hline 2 & Jenis kerupuk \\
\hline 3 & Biaya produksi \\
\hline
\end{tabular}

\begin{tabular}{|c|l|}
\hline No. & Respon Teknis (hows) \\
\hline 4 & Ukuran dan bentuk \\
\hline 5 & Pelayanan pelanggan \\
\hline
\end{tabular}

\begin{tabular}{|c|l|}
\hline No. & Respon Teknis (hows) \\
\hline 6 & Proses produksi \\
\hline 7 & Jaminan kualitas \\
\hline
\end{tabular}

Tanggapan yang diberikan perusahaan terdapat 7 Respon teknis (hows) yang akan digunakan dalam strategi pengembangan produksi kerupuk ikan bandeng. Tahap selanjutnya menghitung tingkat kepentingan terhadap masingmasing atribut kebutuhan konsumen (whats), seperti ditunjukan pada Tabel 3 berikut.

Tabel 3. Tingkat Kepentingan Pelanggan

\begin{tabular}{|c|l|c|c|}
\hline No & Atribut Kebutuhan konsumen (Whats) & Skor & Tingkat Kepentingan \\
\hline 1 & Bahan baku berkualitas baik & 317 & 4,53 \\
\hline 2 & Bahan pendukung berkualitas baik & 315 & 4,50 \\
\hline 3 & Kerupuk ikan sebagai pelengkap makan & 317 & 4,53 \\
\hline 4 & Sebagai makanan camilan ringan & 325 & 4,64 \\
\hline 5 & Harga terjangkau & 330 & 4,71 \\
\hline 6 & Harga sesuai kualitas atau manfaat & 300 & 4,29 \\
\hline 7 & Ukuran dan ketebalan irisan bervariasi & 308 & 4,40 \\
\hline 8 & Bentuk kerupuk ikan yang bervariasi & 319 & 4,56 \\
\hline 9 & Customer sevice untuk keluhan pelanggan & 301 & 4,30 \\
\hline 10 & Jaminan dalam waktu tertentu & 307 & 4,39 \\
\hline 11 & Kerupuk ikan bermotif menarik & 309 & 4,41 \\
\hline 12 & Penggunaan packaging menarik & 312 & 4,46 \\
\hline 13 & Kemudahan memperoleh produk & 311 & 4,44 \\
\hline 14 & Jaminan kesehatan saat konsumsi & 317 & 4,53 \\
\hline
\end{tabular}

Hasil perhitungan terhadap tingkat kepentingan terhadap masing-masing atribut kebutuhan konsumen diperoleh nilai tertinggi pada atribut harga terjangkau sebesar 4,71 sedangkan nilai terendah pada atribut harga sesuai kualitas atau manfaat sebesar 4,29. Selanjutnya menghitung niali tingkat kepuasan pelanggan seperti pada Tabel 4 .

Tabel 4. Tingkat Kepuasan Pelanggan

\begin{tabular}{|l|l|c|c|}
\hline No & Atribut Kebutuhan konsumen (Whats) & Skor & Tingkat Kepentingan \\
\hline 1 & Bahan baku berkualitas baik & 280 & 4,00 \\
\hline 2 & Bahan pendukung berkualitas baik & 277 & 3,96 \\
\hline 3 & Kerupuk ikan sebagai pelengkap makan & 277 & 3,96 \\
\hline 4 & Sebagai makanan camilan ringan & 273 & 3,90 \\
\hline 5 & Harga terjangkau & 291 & 4,16 \\
\hline 6 & Harga sesuai kualitas atau manfaat & 284 & 4,06 \\
\hline 7 & Ukuran dan ketebalan irisan bervariasi & 288 & 4,11 \\
\hline 8 & Bentuk kerupuk ikan yang bervariasi & 298 & 4,26 \\
\hline 9 & Customer sevice untuk keluhan pelanggan & 283 & 4,04 \\
\hline 10 & Jaminan dalam waktu tertentu & 275 & 3,93 \\
\hline 11 & Kerupuk ikan bermotif menarik & 279 & 3,99 \\
\hline 12 & Penggunaan packaging menarik & 290 & 4,14 \\
\hline 13 & Kemudahan memperoleh produk & 289 & 4,13 \\
\hline 14 & Jaminan kesehatan saat konsumsi & 284 & 4,06 \\
\hline
\end{tabular}

Sedangkan hasil perhitungan tingkat kepuasan pelanggan terhadap masing-masing atribut kebutuhan konsumen diperoleh nilai tingkat kepuasan tertinggi pada atribut bentuk kerupuk ikan yang bervariasi dengan nilai 4,26 sedangkan nilai terendah pada atribut sebagai makanan camilan ringan dengan nilai 3,90 .

Copyright (C) 2019, Kaizen : Management Systems \& Industrial Engineering Journal ISSN 15222-96806 (print), ISSN 155222-95973 (online) 


\section{KAIZEN : MANAGEMENT SYSTEMS \& INDUSTRIAL ENGINEERING JOURNAL VOL. 2 NO. 2 TEKNIK INDUSTRI UNIVERSITAS PGRI MADIUN}

2. Perhitungan Bobot Atribut dan Normalisasi Bobot

Setelah diperoleh nilai masing-masing atribut kepentingan dan kepuasan pelanggan maka selanjutnya di menghitung bobot Improvement Ratio, Sales Point, Raw Weight dan Normalized Row Weight, seperti ditunjukan pada Tabel 5 berikut.

Tabel 5. Hasil Perhitungan Bobot Tingkat Kepentingan

\begin{tabular}{|l|c|c|c|c|c|}
\hline \multicolumn{1}{|c|}{ Kebutuhan konsumen (Whats) } & Goal & $\begin{array}{c}\text { Improvement } \\
\text { Ratio }\end{array}$ & $\begin{array}{c}\text { Sales } \\
\text { Point }\end{array}$ & $\begin{array}{c}\text { Raw } \\
\text { Weight }\end{array}$ & $\begin{array}{c}\text { Normalized } \\
\text { Raw Weight }\end{array}$ \\
\hline 1. Bahan baku berkualitas baik & 4 & 1,00 & 1,2 & 5,43 & 0,065 \\
\hline 2. bahan pendukung berkualitas baik & 4 & 1,01 & 1,5 & 6,82 & 0,081 \\
\hline 3. Krupuk ikan sebagai pelengkap makan & 4 & 1,01 & 1,2 & 5,49 & 0,066 \\
\hline 4. Sebagai makanan camilan ringan & 4 & 1,03 & 1,5 & 7,14 & 0,085 \\
\hline 5. Harga terjangkau & 4 & 0,96 & 1,5 & 6,80 & 0,081 \\
\hline 6. Harga sesuai kualitas atau manfaat & 4 & 0,99 & 1,2 & 5,07 & 0,060 \\
\hline 7. Ukuran dan ketebalan irisan bervariasi & 4 & 0,97 & 1,2 & 5,13 & 0,061 \\
\hline 8. Bentuk krupuk ikan yang bervariasi & 4 & 0,94 & 1,2 & 5,14 & 0,061 \\
\hline 9. Customer sevice untuk keluhan pelanggan & 4 & 0,99 & 1,5 & 6,38 & 0,076 \\
\hline 10. Jaminan dalam waktu tertentu & 4 & 1,02 & 1,5 & 6,70 & 0,080 \\
\hline 11. Krupuk ikan bermotif menarik & 4 & 1,00 & 1,2 & 5,32 & 0,063 \\
\hline 12. Penggunaan packaging menarik & 4 & 0,97 & 1,2 & 5,16 & 0,062 \\
\hline 13. Kemudahan memperoleh produk & 4 & 0,97 & 1,5 & 6,46 & 0,077 \\
\hline 14. Jaminan kesehatan saat konsumsi & 4 & 0,99 & 1,5 & 6,76 & 0,081 \\
\hline
\end{tabular}

Dari tabel diatas diperoleh nilai raw weight tertinggi pada atribut sebagai makanan camilan sebesar 7,14, sedangkan nilai terendah yaitu harga sesuai kualitas atau manfaat dengan nilai 5,07. Sedangkan nilai tertinggi normalized raw weight yaitu pada atribut sebagai makanan camilan ringan dengan nilai sebesar 0,085 . Selanjutnya menyusun hubungan antara atribut kebutuhan konsumen terhadap respon teknis ditunjukan pada tabel technical matrix berikut.

Tabel 5. Technical Matrix Produk Kerupuk Ikan Bandeng

\begin{tabular}{|c|c|c|c|c|c|c|c|}
\hline Kebutuhan konsumen (whats) & 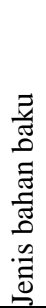 & 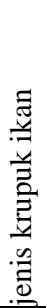 & 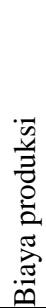 & 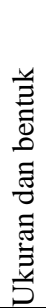 & 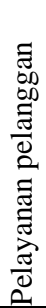 & 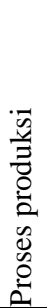 & 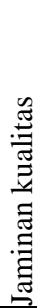 \\
\hline 1. Bahan baku berkualitas baik & 9 & & 3 & & & 3 & \\
\hline 2. bahan pendukung berkualitas baik & 9 & & 3 & & & 3 & \\
\hline 3. Krupuk ikan sebagai pelengkap makan & & 9 & & & & & \\
\hline 4. Sebagai makanan camilan ringan & & 3 & & & & & \\
\hline 5. Harga terjangkau & & & 9 & & & & \\
\hline 6. Harga sesuai kualitas atau manfaat & & & 9 & & & & \\
\hline 7. Ukuran dan ketebalan irisan bervariasi & & & 3 & 3 & & 3 & \\
\hline 8. Bentuk krupuk ikan yang bervariasi & & & & 9 & & 3 & \\
\hline 9. Customer sevice untuk keluhan pelanggan & & & & 1 & 9 & & \\
\hline 10. Jaminan dalam waktu tertentu & & & & & 9 & 9 & \\
\hline 11. Krupuk ikan bermotif menarik & & & & & & 9 & \\
\hline 12. Penggunaan packaging menarik & & & & & & 3 & \\
\hline 13. Kemudahan memperoleh produk & & & & & & & 9 \\
\hline 14. Jaminan kesehatan saat konsumsi & & & & & & & 3 \\
\hline
\end{tabular}

Penyusunan technical matrix diperolah bahwa adanya hubungan yang kuat antara atribut kebutuhan konsumen terhadap respons teknis, dimana bahan baku berkualitas baik dan bahan pendukung mempunyai pengaruh tinggi terhadap jenis bahan baku yang akan diproduksi. Sedangkan dari harga dan kualitas, konsumen menginginkan adanya harga yang terjangkau sehingga biaya produksi harus lebih dipertimbangkan.

Copyright (C) 2019, Kaizen : Management Systems \& Industrial Engineering Journal ISSN 15222-96806 (print), ISSN 155222-95973 (online) 


\section{KAIZEN : MANAGEMENT SYSTEMS \& INDUSTRIAL ENGINEERING JOURNAL VOL. 2 NO. 2 TEKNIK INDUSTRI UNIVERSITAS PGRI MADIUN}

3. Penyusunan House of Quality

Dalam menyusun HoQ, langkah yang dilakukan adalah menentukan keinginan konsumen dan karakteristik pengembangan produk yang akan dilakukan yang ditentukan melalui hubungan dengan simbol, seperti pada gambar 1 dibawah ini.

\begin{tabular}{|l|c|}
\hline \multicolumn{2}{|c|}{ Correlations } \\
\hline Positive & + \\
\hline Negative & - \\
\hline Non Correlation & \\
\hline
\end{tabular}

\begin{tabular}{|l|c|}
\hline \multicolumn{2}{|c|}{ Relationships } \\
\hline Strong & $\bullet$ \\
\hline Moderate & $\circ$ \\
\hline Weak & $\Delta$ \\
\hline
\end{tabular}

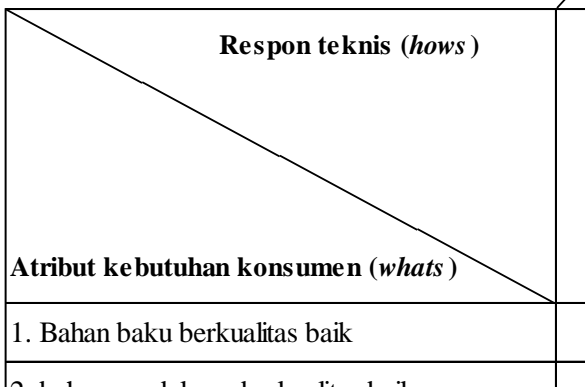

2. bahan pendukung berkualitas baik

3. Krupuk ikan sebagai pelengkap makan

4. Sebagai makanan camilan ringan

5. Harga terjangkau

6. Harga sesuai kualitas atau manfaat

7. Ukuran dan ketebalan irisan bervariasi

8. Bentuk krupuk ikan yang bervariasi

9. Customer sevice untuk keluhan pelanggan

10. Jaminan dalam waktu tertentu

11. Krupuk ikan bermotif menarik

12. Penggunaan packaging menarik

13. Kemudahan memperoleh produk

14. Jaminan kesehatan saat konsumsi

\begin{tabular}{|c|c|c|c|c|c|c|c|c|c|c|c|c|}
\hline 14. Jaminan kesehatan saat konsumsi & & & & & & & O & 4 & 0,99 & 1,5 & 6,76 & 0,08 \\
\hline Contribution & 1,32 & 0,59 & 0,44 & 0,08 & 1,40 & 1,91 & 0,94 & & & & & \\
\hline Relative Contribution (\%) & $19,7 \%$ & $8,8 \%$ & $6,6 \%$ & $1,1 \%$ & $21,0 \%$ & $28,7 \%$ & $14,0 \%$ & & & & & \\
\hline Ranking Technical Response Priority & 3 & 5 & 6 & 7 & 2 & 1 & 4 & & & & & \\
\hline
\end{tabular}

Gambar 1. House Of Quality Pengembangan Produk Kerupuk Ikan Bandeng Gresik

4. $\quad$ Analisis Hasil Matriks House of Quality (HoQ)

Berdasarkan hasil perhitungan yang telah dilakukan maka diperoleh nilai contribution untuk masing masing respon teknis dan rangking technical response priority yang dijadikan sebagai acuan dalam menentukan prioritas pengembangan produk kerupuk ikan bandeng di Kabupaten Gresik. 


\section{KAIZEN : MANAGEMENT SYSTEMS \& INDUSTRIAL ENGINEERING JOURNAL VOL. 2 NO. 2 TEKNIK INDUSTRI UNIVERSITAS PGRI MADIUN}

Tabel 6. Nilai Contribution dan Rangking Technical Response Priority

\begin{tabular}{|c|l|c|c|}
\hline No & Respon Teknis & Contribution & Relative contribution (\%) \\
\hline 1 & Proses produksi & 1,91 & $28,7 \%$ \\
\hline 2 & Pelayanan pelanggan & 1,40 & $21 \%$ \\
\hline 3 & Jenis bahan baku & 1,32 & $19,7 \%$ \\
\hline 4 & Jaminan kualitas & 0,94 & $14 \%$ \\
\hline 5 & Jenis kerupuk ikan & 0,59 & $8,8 \%$ \\
\hline 6 & Biaya produksi & 0,44 & $6,6 \%$ \\
\hline 7 & Ukuran dan bentuk & 0,08 & $1,1 \%$ \\
\hline
\end{tabular}

5. Hasil Pengembangan Produk Kerupuk Ikan Bandeng Gresik

Berdasarkan hasil penyusunan matrik maka dketahui bahwa nilai contribution tertinggi pada respon teknis yaitu proses produksi dengan nilai contribution sebesar 1,91 dan nilai relative contribution sebesar $28,7 \%$. Pengembangan yang dilakukan yaitu:

a) Melakukan perbaikan proses produksi dari mulai penggunaan bahan baku utama yaitu ikan bandeng dengan ukuran yang seragam. Pengolahan yang sesuai dengan standar keamanan untuk makanan. Penggunaan mesin giling yang higienis. Kebersihan dan sterilisasi ruang produksi. Proses penjemuran dengan oven untuk menghasilkan kualitas kerupuk ikan yang mempunyai tingkat kekeringan merata. Penggunaan bahan pewarna makanan yang mempunyai standar keamanan untuk dikonsumsi.

b) Memberikan pelayanan pelanggan melalui sistem terintegrasi dengan media sosial untuk memberikan informasi yang dibutuhkan oleh konsumen, terkait dengan keluhan dan proses transaksi pembelian serta promosi.

c) Mendesain bentuk kerupuk yang baru dengan motif menarik sesuai dengan keinginan konsumen dengan ukuran yang bervariasi sehingga daya beli konsumen meningkat.

\section{Simpulan}

Dari hasil pengembangan produk UKM kerupuk ikan bandeng di Kabupaten Gresik, atribut - atribut yang dapat diprioritaskan pertama adalah perbaikan proses produksi dari mulai penggunaan bahan baku utama yaitu ikan bandeng dengan ukuran yang seragam. Pengolahan yang sesuai dengan standar keamanan untuk makanan. Penggunaan mesin giling yang higienis. Kebersihan dan sterilisasi ruang produksi. Proses penjemuran dengan menggunakan oven untuk menghasilkan kualitas kerupuk ikan yang mempunyai tingkat kekeringan merata. Pengembangan yang kedua yaitu memberikan pelayanan pelanggan melalui sistem terintegrasi dengan penggunaan teknologi informasi. Pengembangan yang ketiga yaitu pembuatan desain bentuk dan ukuran dengan motif sesuai dengan keinginan konsumen.

\section{Daftar Pustaka}

[1] R. S. Putra and Y. I. Karimah, "Pengelolaan Sumber Daya Manusia Untuk Memulai Usaha Olahan Bandeng Di Desa Jenggolo Sidoarjo," Community Dev. J., vol. 1, no. 1, pp. 12-15, 2017.

[2] KKP, "Refleksi 2018 dan Outlook 2019 Kementerian Kelautan dan Perikanan," 2018.

[3] K. Kustini, Y. Yuniningsih, and S. Winarti, "Pelatihan Pemanfaatan Limbah Duri Bandeng Sebagai Bahan Pembuatan Krupuk Stik Di Kelurahan Gunung Anyar Tambak Kecamatan Rungkut Surabaya," PEDULI, vol. 2, no. 2, pp. 56-65, 2019.

[4] K. T. Ulrich and S. D. Eppinger, Perancangan dan Pengembangan Produk. 2001.

[5] A. Kasan and A. Yohanes, "Improvement Produk Hammock Sleeping Bag dengan Metode QFD (Quality Function Deployment)," J. Ilm. Din. Tek., vol. 10, no. 1, pp. 40-49, 2017.

[6] A. Hanafie, Musrawati, and Asti, "Analisis Strategi Pengembangan Produksi Gula Merah Cair Pada IKM Gula Merah Cair Dengan Menggunakan Metode QFD,” 2018.

[7] H. Maulana and S. Suhartini, "Pengembangan Produk Meja Sablon Semi Otomatis Dengan Menggunakan Metode QFD," J. TECNOSCIENZA, vol. 2, no. 2, pp. 20-41, 2018.

[8] L. Cohen, Quality function Deployment: How To Make QFD Work For You. Prentice Hall, 1995.

[9] T. Wijaya, Manajemen Kualitas Jasa Desain Servqual, QFD, dan Kano. 2011. 
KAIZEN : MANAGEMENT SYSTEMS \& INDUSTRIAL ENGINEERING JOURNAL VOL. 2 NO. 2 TEKNIK INDUSTRI UNIVERSITAS PGRI MADIUN

[10] B. Chrisdiyanto, "Perancangan Dan Pengembangan Meja Belajar Lipat Multifungsi Yang Ergonomis Menggunakan Metode QFD (Quality Function Deployment).” Universitas Muhammadiyah Surakarta, 2014.

[11] F. Mantika, Z. Arifin, and V. M. Afma, "Pengembangan Desain Poduk Bantal Sofa Untuk Memenuhi Kebutuhan Konsumen Dengan Metode Quality Function Deployment (QFD) Di CV Pili Pilo Indonesia," PROFISIENSI, vol. 5, no. 2, pp. 92-7, 2018.

[12] I. Sulistiawan, H. B. Santoso, and A. Komari, "Perancangan Produk Kep Potong Rambut Dengan Mempertimbangkan Voice Of Customer Menggunakan Metode Quality Function Deployment," JATI UNIK J. Ilm. Tek. dan Manaj. Ind., vol. 2, no. 1, pp. 43-50, 2019. 